\title{
How the Croatian Daily Press Presents Science News
}

\section{Adrijana Šuljok and Marija Brajdić Vuković}

\begin{abstract}
Research into media representations of science is widespread and well-established in scientifically and technologically highly developed countries. However, very little is known about the characteristics of media reporting of science in transition countries, which are only just beginning to recognize the importance of research into the relationship between science, the media and the public. In this study, using content analysis of the daily newspapers with the largest circulations in Croatia (Jutarnji list and Večernji list) we researched the quantity and quality of media reporting of science. We link them to the characteristics of the Croatian media (tabloidization, the erosion of professional criteria) and the wider social context from which they stem. Our findings have shown poor representation of science news in the daily press as well as a low level of trustworthiness, especially in reporting biomedical news.
\end{abstract}

Keywords: Science coverage, Media, Croatia

\section{Introduction}

Recent social constructivist approaches to the media's presentation of science claim that the media (and the public) are active participants in the process of construction and communication of knowledge (van Dijck, 2003). That is to say, the process of competition and selection of news takes place in the public arena of the media, where journalists and editors assess the newsworthiness of individual news items (Hilgartner \& Bosk, 1988). They select and shape the topics and aspects which they perceive as relevant, important or interesting. News are constructed and shaped according to the accepted standards and conventions of the organization in which the journalist works. Those standards and conventions are most often quite similar to the culture context in which the media exists (Nelkin, 1995; Lievrouw, et al., 1990, see Dimopoulus \& Koulaidis, 2002). Therefore, the selection and framing of news are socially and culturally conditioned.

There are several reasons why the analysis of media coverage of science has caught the attention of researchers. Firstly, the media is an important source of information about science (Nelkin, 1995), and it has a specific role in achieving "scientific literacy." Secondly, media analysis can contribute to a better understanding of the social position of science. Many researchers have identified and analysed the dominant characteristics and trends in the media reporting of science in order to learn indirectly which definitions and opinions about science are promoted 
and legitimized by various social factors, or what society thinks and knows about science (Anderson et al., 2005; Lewenstein, 1995; Bauer et al., 2006). Researchers study media as one of the (cultural) indicators showing the evaluation and position of science in society (Bauer, 2000). Thirdly, the media is an important part of the public sphere that reflects and forms public opinion.

More recent research into the forms and trends in media communication of science, undertaken in scientifically and technologically developed countries, has primarily shown the following characteristics of the media image of science.

First, scientific themes are not highly represented in the structure of topics covered by the daily press, but over time, there has been a noticeable (absolute and relative $^{1}$ ) increase in science coverage in some types of media (Clayton et al., 1993; Pellechia, 1997; Bucchi \& Mazzolini, 2003; Bauer et al. 2006; Elmer et al. 2008). This may be explained by the more rapid flow of information, the introduction of specialized science columns and supplements (Bader, 1990; Bucchi \& Mazzolini, 2003), and also by the process Weingart (1998) calls the "medialization" of science.

Second, science, despite the rise of criticism, is dominantly presented in the media as progressive and consensual activity (Nelkin, 1995; Dimopoulos \& Kouladis, 2002; van Rooyen, 2002). Third, media reports covering scientific topics mostly omit the methodology and contextual background, which may be a key to understanding scientific events (Pellechia, 1997; Dimopoulos \& Kouladis, 2002). Fourth, in reporting on scientific topics there is a predominance of biomedical sciences (e.g. Bauer, 1998; van Rooyen, 2002; Bucchi \& Mazzolini, 2003), which are becoming the prototype of the public image of science (Durant et al. 1992; Bauer, 1998; Verhoeven, 2008).

Researchers in this field have indicated that science news in general is largely considered "soft news" due to the insufficient (media) attractiveness of scientific findings and because the importance of science news is not always direct or immediately visible (Hansen, 1994; Weigold, 2001).

However, these studies were mainly undertaken in (Western) democratic countries, which have a high level of economic, scientific and technological development and a certain tradition of public understanding of science as a "movement" and research discipline (e.g. Clayton et al., 1993; Pellechia, 1997; Bucchi \& Mazzolini, 2003; Bauer et al., 2006; Elmer et al., 2008).

Because transitional countries went through late social changes, they are only just beginning to recognize the importance of research into the relationship between science, the media and the public. This is why studies on the media's coverage of science are very rare and why so little is known about the characteristics of media reporting of science in these countries ${ }^{2}$. A British-Bulgarian comparative study (Bauer et al., 2006) has already indicated some of the special features of Bulgarian reporting of science, and thereby confirmed the importance of the socio-cultural milieu as the social framework in which science news is selected and framed.

Apart from a lack of knowledge about the situation regarding the reporting of science in Croatia, there are several reasons why we consider the analysis of science coverage in Croatia, as a transitional society, an important research topic. The existing studies of media representation of science in non-Western countries are very rare (Schäfer, 2010). Therefore, knowledge of science coverage in the media is largely dominated by science images in highly 
developed countries. Moreover, few comparative studies of highly developed and transitional countries (e.g. the already mentioned comparative British-Bulgarian study) point to certain specificities and possible differences in media selection and approach to science topics, arising from differences between societies. Many researchers have suggested that the sociocultural milieu is an important factor that shapes media practices and "journalistic culture." Forexample, Guyot(2009:92)argues that the actual local "journalistic practice is strongly marked by national historical situations and values linked to a particular context in which the media were built". Similarly, the media coverage of science is also shaped by broader sociopolitical and sociohistorical contexts, social values, general attitudes toward science, etc. This is why generalizations about media coverage of science that are based on analyses in developed democracies and in democratic, highly professional media should not be considered adequate enough for analysing and understanding media representation and science communication in transitional societies.

Despite many similarities in the sociohistorical legacies of former socialist countries, some remarkable specificities have marked the transformation of each of these countries. As a part of former Yugoslavia, the media in Croatia had greater freedom in comparison with other socialist countries and could have had a relatively "successful" media transformation. Unfortunately, the transition process in Croatia has been characterized by very turbulent transformations that began during the war and led to social, political and media specificities and deviations.

Therefore, the media image of science in Croatia may be a research topic of wider interest. Croatia is a transitional country in which the media have only recently begun to become democratic and commercial and in which, due to a preoccupation with the major social, political and economic transformations, science primarily has only declarative social relevance.

\section{Croatian Context}

It is difficult to objectively assess the quality of the printed media in Croatia today. The liberalization of the media began at the end of the 1980s. Over the past twenty or so years, the printed press, as well as other types of media in Croatia, have gone through many legislative, ownership and economic changes (privatization, demonopolization), which are also reflected in the editorial concept of newspapers. Democratization and the expansion of commercial media have greatly altered the media, which have taken on market characteristics. On a wider social plane, there is an increasingly obvious link between the media, politics and the market. There is no longer a threat of control nor are there displays of power by the state, but instead, by major media corporations (Valković, 2009). ${ }^{3}$

However, the transition from state ownership towards the mass media market does not necessarily mean an increase in the quality of information (Jergović, 2004a). Guyot (2009) points out that the media and journalists in transitional countries had to deal with previously unknown market pressures and very rapid changes. The previous "social responsibility" of the socialist press (Robinson, 1977), seen plainly in their responsibility towards the state political order and ideology (Vujević, 2001; Jergović, 2004a), has been replaced by tabloidization, sensationalism and an increasing proportion of "soft news" and infotainment (Kronja, 2008; Jergović, 2004a). 
According to some assessments, the printed media in Croatia in the 1990s - under the influence of a multitude of transitional factors and the spread of tabloidization - became a media of sensationalism and journalism of questionable quality. Professional and ethical standards became seriously threatened as well (Jergović, 2004a; Skoko \& Bajs, 2007). The educational level of journalists in the new media context decreased. According to data from the Croatian Journalists' Association from 2004, $60 \%$ of journalists who were members of the association and $75 \%$ of young journalists who were yet to become members did not have a university degree (Jergović, 2004b: 400).

Today, analysis of the characteristics and consumption of the Croatian media shows that the printed media have a large share of the market within it. According to research into the frequency of use of individual media in Croatia, the printed media occupy third place, after television and radio (Peruško Čulek, 1999: 176). In 2004, immediately before this research was conducted, according to data from the agency Puls, the daily press was read on average by $44 \%$ of the Croatian population ${ }^{4}$.

The Croatian public is characterised by a very small proportion of people with higher education, accounting for only $\mathbf{8 \%}$ of the total population (Croatian Bureau of Statistics - CBS). From the rare research into the Croatian public related to the daily press, we have learned that women in Croatia, for example, mainly read the accident and crime news ("The black chronicles") as well as local news and entertainment, while science is not even amongst the top ten topics which the average female audience in Croatia finds interesting (Kunac \& Sarnavka, 2006). Therefore the data on the scientific literacy of the Croatian public is not surprising; although not completely disappointing, the data shows a definite lag behind scientifically and technologically more developed countries (Eurobarometer, 2005: 41). Moreover, domestic surveys show both - scepticism and trust - in the cognitive and social benefits of science (Prpić, 2011).

It is therefore not surprising that science journalism was not able to develop in these circumstances. This was certainly encouraged by the intensity of the social transformations in all spheres of society (political and economic transition), which directed the media's attention towards the current radical social, political and economic changes on the one hand, and towards light and entertaining content on the other. Science, as in many other former socialist countries, was considered primarily as expenditure and marginal activity.

\section{Aims of the Study}

Since no similar studies have been conducted previously in Croatia, the main objective of this paper is to examine the dominant quantitative and qualitative characteristics of the presentation of science in the most widely read Croatian daily press. Emphasis is placed on identifying the basic formal characteristics of media reporting on science, examining the differences in science coverage between the two leading daily newspapers, examining the differences in the presentation of different scientific disciplines and acquiring basic data about trustworthiness of science coverage. Ultimately, the results are linked with a broader social and media context of a transitional Croatian society, bearing in mind the dominant patterns and trends in media communication of science in developed Western societies. Approaches and results from "western" studies are used only as methodological referent points and frames, as a means for developing instruments and collecting data, without the intention of comparing results. This is 
due to the differences in the selection and definition of science news, media types, analysed time periods, etc.

Media credibility, as a complex and multidimensional concept, has long been a research topic in media studies. Researchers point out two types of media credibility: source credibility (trustworthiness of the individual sources, Hovland \& Weiss, 1951) and news medium credibility (the overall credibility of television and newspapers, Graziano \& McGrath, 1986). Our index is more modestly conceived, and it measures only one part of this complex concept it manifests impartiality and integrity of media reports. More precisely, in this study we define trustworthiness as an approach to scientific news in terms of the quality of information processing. Due to the fact that the index was post-hoc constructed from the available data, we could not dig deeper into other media credibility dimensions.

Kurtić (2007) indicates the following elements as relevant indicators of manifest impartiality and integrity of media reports: (types of) quotes and citations ${ }^{5}$, listing sources of information $^{6}$, depth and scope of the verification of information ${ }^{7}$, confrontation of information and sources, quantitative relationship between factographic, and finally, interpretative elements. More specifically, researchers indicated that a better quality text will have more of the already mentioned indicators - statements, quotations and additional information (indepth approach), and only a text that clearly defines its sources of information can be considered trustworthy (Kanižaj, 2007; Žlof, 2007; Malović, 2007).

Taking into account the availability and nature of the analysed articles, we have reduced the indicators to the following elements: sources of information, quotations of experts and in-depth approach. Thus our instrument has some limitations (e.g. no evaluation of source credibility, inclusion of only some dimensions), but it still represents a simple measure for analysing the basic differences in media reporting trustworthiness. Deeper analysis would certainly require further upgrading and introducing other approaches for analysing media trustworthiness.

\section{Method}

In order to achieve our basic goal, the research was founded on the content analysis of articles about science published in the period between December 31, 2004 and February 28, 2005 (a total of 116 issues) in two of the most widely read Croatian daily papers, which are also the leading papers of two media corporations: Jutarnji list (EPH) and Večernji list (STYRIA) (MEDIAPuls, 2004.). The average circulation of Jutarnji list in 2004 was $41 \%$ and for Večernji list $38 \%$ of the country's population aged 15 years and over.

We acknowledge that an analysis of media coverage of science cannot be reduced solely to the press. However, the fact is that most researchers, due to economic and availability restrictions, analyse the press, most often the elite daily press. This study is also determined by availability and costs of the research data. Further important reason for choosing the press was the possibility of expanding a future study to newspapers from the past and then comparing the results. By choosing the two most widely read daily papers rather than elite ones, we attempted to acknowledge the criticism aimed at researchers, saying they should move away from researching the elite press since it is over-represented in relation to its readership (Evans \& Priest, 1995).

Since our study is the first of its kind in Croatia, we chose the convenience sample (2 months) to gain basic insights into the media image of science in Croatian most- 
read daily papers as well as its specificities. It also allowed us to identify key variables for further upgrading and analyses.

Research into the presentation of certain (non-scientific) types of news in the Croatian daily press has led to the conclusion that, in terms of content and presentation of the news, these leading papers can be defined as "semi-tabloids" (Dragojević et al., 2006). Neither of these newspapers has a separate daily or weekly section dedicated to scientific topics - newspaper supplements mainly focus on other topics, and science news most often competes with other types of news.

The basic unit of analysis were those articles that explicitly reported the results of scientific research (including presentation of scientific discoveries), reported on scientific events (conferences, symposia, seminars and workshops) or gave reviews of science books or portraits of scientists. For research purposes, these articles were called science news, and a total of 360 were identified. Articles dealing with events related to science (or higher-education) policy, such as the Bologna Process, or those in which scientists appeared as commentators on current social topics and events (e.g. presidential elections), were excluded from the analysis.

Science news was analysed by using a code matrix adapted to the needs of our research. The code matrix (appendix) was developed by combining elements from previously conducted and published foreign studies that used content analysis to examine various aspects of reporting on science, as well as elements relevant to establishing the basic characteristics of the presentation of science (e.g. thematic division of sections). Coding articles about science was undertaken using mainly manifest variables, such as an announcement on the front page, the length of the article, the use of graphics, and by avoiding variables that demand a subjective value judgement as much as possible. This increased the reliability of the coding.

The coding was done by the authors of this paper using the printed (paper) copies of daily newspapers, rather than an electronic archive, due to its limitations ${ }^{9}$. All coded articles were selected after carefully reading the complete article according to the agreed guidelines. The data was processed in SPSS, and the following statistical analyses were used: chi-square test, linear regression, T-test and one-way ANOVA.

\section{Results}

\section{The Formal Characteristics of Science News}

\section{Size and Frequency}

In a two-month period, a total of 360 articles defined as science news were found and analysed. 163 of the articles (45.3\%) were published in Večernji list and 197 articles (54.7\%) in Jutarnji list. About half of the science news published in both papers (Večernji - 54.9\%, Jutarnji - 47.2\%) covered only one quarter of a page. If we take into account the total number of articles in both papers, the proportion of science news in both daily papers in a period of two months was only $2.3 \%$. However, t-tests showed that the analysed dailies differ significantly according to the average proportion of articles about science $(\mathrm{t}=-2.399, \mathrm{df}=1$, Sig.=.000). The proportion was significantly larger in Jutarnji list (2.63\%) than in Večernji list, averaging $1.93 \%$.

\section{Position and Character of the Sections}

Only $2.5 \% \quad(\mathrm{~N}=5)$ of the articles were announced on the front page of Jutarnji list and $0.6 \%$ (1) in Večernji list. The largest number of science news throughout one week was published on the back pages of both newspapers (Večernji list - 28\%, 
Jutarnji list - 27\%). More than half of the news published on the back pages fell into the category of regular articles in Jutarnji called "Good News" and "Bad News" and in Večernji "IN" and "OUT". Both newspapers used special colours to categorize their regular articles ("Bad News" and "OUT" were coloured red, while "Good News" and "IN" were blue-green or green). As a rule, these articles were located at the bottom left-hand corner of the page. The location and average space used was less than $15 \%$ of the page, showing that the news published under these headings were truly marginal, and in visual terms, almost excluded from the page.

The thematic division of sections and supplements into serious, mixed and entertainment enabled a more detailed analysis of the positioning of science news within the paper ${ }^{10}$. Serious sections and supplements were those whose content was primarily news or analysis of daily socio-political events. Mixed supplements and sections contained both serious and entertaining news, and the back page of both papers often featured (apart from entertaining news) the latest serious news items, which usually arrived "at the last minute" just before going to print. The supplements and sections described as entertainment were those that primarily dealt with topics such as fashion and home decorating, beauty and show business.

Most of the science news items in both papers were published in serious sections of the paper (Jutarnji $45.4 \%$, Večernji $45.7 \%$ ), and a little less than one quarter were published in the "mixed" sections (Jutarnji 23.9\%, Večernji 17.3\%). Although Jutarnji list and Večernji list did not differ significantly regarding the characteristics of the sections in which they published science news, Večernji list had a slight tendency to report science news more often in sections of an entertaining nature (Jutarnji 30.7\%, Večernji $37.1 \%)$.

\section{Journalistic Form}

The reluctance of journalists to show interest in research work and editors to allocate more space for science was evident from the fact that more than half the science news published in both papers fell under the journalistic form "(short) news" (Table 1). Still, Jutarnji list used this form of journalism less often in comparison with Večernji list, but published significantly more commentaries, critical reviews and analyses, which represented about one quarter of the total science news in that paper.

Table 1. The journalistic form of science news articles ( $\mathrm{N}=360)$.

\begin{tabular}{|c|c|c|c||}
\hline & Večernji list & Jutarnji list & Total \\
\hline News, information & $60.1 \%$ & $50.3 \%$ & $54.7 \%$ \\
\hline Report, feature & $22.7 \%$ & $20.3 \%$ & $21.4 \%$ \\
\hline $\begin{array}{c}\text { Commentary, critical } \\
\text { review, analysis }\end{array}$ & $12.3 \%$ & $25.4 \%$ & $19.4 \%$ \\
\hline $\begin{array}{c}\text { Interview } \\
\text { Combination of } \\
\text { elements }\end{array}$ & $3.1 \%$ & $2.0 \%$ & $2.5 \%$ \\
\hline Total & $1.8 \%$ & $2.0 \%$ & $1.9 \%$ \\
\hline
\end{tabular}

$\chi^{2}=14.004, \mathrm{df}=4$, Sig. $=0.016$ 


\section{Graphic Design and Appearance}

Science news articles have an abundance of graphic illustrations and about $70 \%$ of them were enriched with illustrations in both newspapers, which in $95 \%$ of cases were photographs. Apart from rare cases, such as a photograph of a plant, the graphics usually did not aid in better understanding the scientific content. They were "visually attractive" photographs, not related to the content of the text, such as a woman eating, children playing or people in a park. Illustrations that could help explain science news or complement them were used extremely rarely, in only $1 \%$ of news items.

\section{Types of Science News}

The press prefers science news about scientific research results or about the application of scientific results (Table $2)$, which is in accordance with the observation of the domination of socalled "gee-whizz" subject matter, a large number of "spectacular" discoveries and breakthroughs (Jerome, 1986). Apart from the results of research, which accounted for more than half the news, in Jutarnji list another quarter of the science news is related to presentations of scientific publications (books, journals) whilst in Večernji about the same proportion consisted of presentations of areas of science, portraits of scientists and/or their work.

\section{How Science News is Reported}

The media frequently omit methodological and contextual information, the exact elements which some authors mention as critical for a complete newspaper report on scientific topics (e.g. Pellechia, 1997). Considered in total, science news in both newspapers stayed mainly on the level of description, which means that about $70 \%$ of this news did not deal with causes and consequences, nor did they give detailed descriptions of processes or events.

Science news items were mainly written by journalists in both papers (Večernji list, 35\%; Jutarnji list, 50\%). However, we noted statistically significant differences in "news authors" $\quad\left(\chi^{2}=42.860, \quad \mathrm{df}=4, \quad\right.$ sig. $\left.=0.000\right)$. Scientists were the authors of articles to a significantly greater extent in Večernji list than in Jutarnji list (3.6\%), but they still amounted to only 8\%. Jutarnji list emphasizes more agency news (35\%), and a large number of news items, as many as $18 \%$, in Večernji list are unsigned, whilst in Jutarnji there are significantly fewer of these (9.1\%).

Table 2. Types of science news by daily paper.

\begin{tabular}{|c|c|c|c|}
\hline & Večernji list & Jutarnji list & Total \\
\hline $\begin{array}{c}\text { News on scientific research } \\
\text { results }\end{array}$ & $53.4 \%$ & $55.8 \%$ & $54.7 \%$ \\
\hline $\begin{array}{c}\text { Conferences, symposia, } \\
\text { promotions }\end{array}$ & $8.6 \%$ & $5.1 \%$ & $6.7 \%$ \\
\hline $\begin{array}{c}\text { Presentation of fields of science, } \\
\text { portraits of scientists }\end{array}$ & $26.4 \%$ & $13.2 \%$ & $19.2 \%$ \\
\hline $\begin{array}{c}\text { Presentation of scientific books or } \\
\text { journals }\end{array}$ & $11.7 \%$ & $25.9 \%$ & $19.4 \%$ \\
\hline Total & $100.0 \%$ & $100.0 \%$ & $100.0 \%$ \\
\hline
\end{tabular}

$\chi^{2}=19.128 \mathrm{df}=3$ Sig. $=0.000$ 
Statistically significant differences were also found in the category "identification of actors" ( $\chi^{2}=14.232, \mathrm{df}=1$, sig. $\left.=0.000\right)$. In about half of their science news articles (55.3\%), Jutarnji list published the full names of the actors the article is about, whilst in Večernji list only one third of the news items gives their precise names $(39.9 \%)$, and in the other third $(36.8 \%)$ they give attributes such as "Italian, Czech scientists" or general terms like "meteorologists," "experts," and "doctors." When it came to news on scientific research and the applications of research, Večernji list mentioned the exact names of the people involved in the research in only one quarter of these news items, compared to almost one half in Jutarnji list. The precise name of the institution where the person came from or in whose name he/she was speaking was given even more rarely in both papers. In Jutarnji list the institution name was given in one third of the articles and in only one quarter of the articles in Večernji list.

\section{Construction of the Trustworthiness Index}

In order to create a clear picture of the treatment of science news in the two daily papers, and taking into account the known characteristics of Croatian media context, we constructed an index of the trustworthy reporting of science news.

The index is a composite scale formed by adding up the results obtained from four variables which represent the elements of trustworthy reporting of science news. These are variables which establish whether the primary source of information is given in the article ( $0=$ no, $1=$ yes), then whether an additional source of information is given $(0=$ no, $1=$ yes $)$, whether the opinion of an expert as a "trustworthy" source is cited (quotations by experts; $0=$ no, $1=$ yes), and how the article is presented ( $0=$ superficially, $1=$ in depth (causes, consequences)), that is, whether the causes and effects are taken into account. By adding up the answers, a scale is obtained with a range of 0 to 4 , where 0 is the lowest level of seriousness, and 4 the highest (Cronbach Alpha=0.71). The index of trustworthiness of science news reporting gives a simple overview of the journalists' and editors' approach to science news in various categories.

In line with the results already described, the t-test $(\mathrm{t}=4.493, \mathrm{df}=358, \quad$ Sig. $=0.000)$ showed that Jutarnji list attained on average a significantly higher result on the trustworthiness index of science reporting (1.82) in comparison with Večernji list (1.14).

Linear regression analysis was performed to identify statistically significant predictors ("formal characteristics" as independent variables) of the trustworthiness index (as a dependent variable). Regression analysis indicates the spatial and graphical characteristics (page number, coverage of space, graphics) as significant predictors of the trustworthiness of reporting science news (regression model explained $38 \%$ of the variations, F-ratio=34.763 sig.=0.000). Trustworthy science news is characterised by being located closer to the front page of the paper. This is the result of the fact that the front page usually carries news which are dealt with more detail, given more space on the page and accompanied by graphics and illustrations.

The analysis of the trustworthiness difference between the two papers is particularly interesting in terms of the type of science news (Graph 1). Apart from the fact that Večernji list lags behind Jutarnji in trustworthiness of presentation of all types of news, one-way ANOVA performed on both papers showed that they were least trustworthy when dealing with the results of scientific research, which is also the category of science news most present in the press. When reporting the results of scientific 


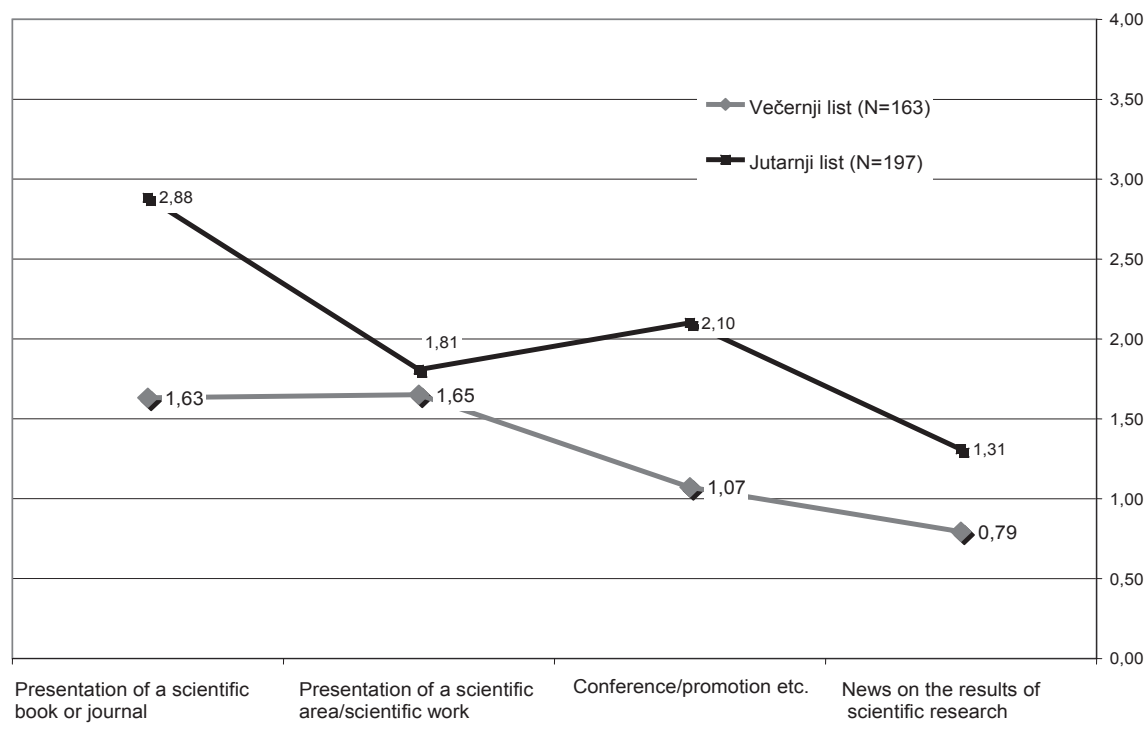

Večernji list: $\mathrm{F}=7.007, \mathrm{df}=3$, Sig. $=0.000 ;$ Jutarnji list: $\mathrm{F}=19.068$, $\mathrm{df}=3$, Sig. $=0.000$

Graph 1. Average value of trustworthiness index when reporting science news, according to type of news.

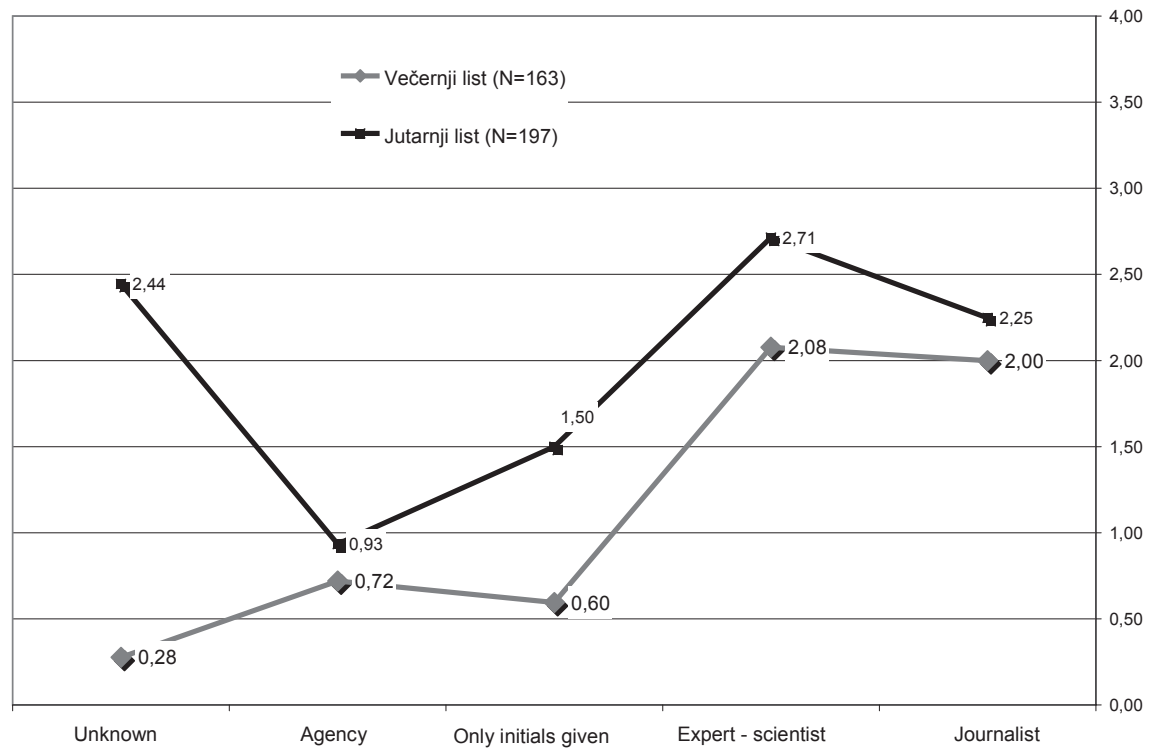

Večernji list: $\mathrm{F}=26.129, \mathrm{df}=4$, Sig. $=0.000 ;$ Jutarnji list: $\mathrm{F}=12.688, \mathrm{df}=4$, Sig. $=0.000$.

Graph 2. Average value of the trustworthiness index, according to author of news. 
research, Jutarnji list met on average at least one of our criteria, while Večernji list on average almost never met even one.

Analysis (one-way ANOVA) of the average value of the trustworthiness index in both dailies indicated significant differences between different "news authors" (Graph 2).

The most "serious" authors of articles in both papers were science experts, although relatively few of them were listed as authors: only $8 \%$ in Večernji list and about $4 \%$ in Jutarnji list. Next came journalists who on average respected at least two of the four criteria of trustworthiness of reporting in both papers. In Večernji list's articles where the author is unknown, it was usually impossible to find even one piece of information which gave the article even some form of legitimacy. Jutarnji list, on the other hand, made up for unknown authorship with at least two of the four pieces of information, making the article trustworthy. In Jutarnji list, agency news reports were the least reliable, which accounted for as much as $30 \%$ of the total science news in that paper. If we excluded from our analysis news which did not meet at least one of the mild criteria - articles where no author was indicated, agency news and news signed with initials only the amount of science news in Večernji list would literally be halved, and its share in the total number of articles would fall to less than $1 \%$.

\section{Coverage of Scientific Fields}

The biomedicine field was covered to a slightly larger extent than other fields in content analysis of news in both newspapers. This is to some extent in line with the trend of the "medicalization" of the media image of science, recorded in other studies (Pellechia, 1997; Bauer, 1998; Bucchi \& Mazzolini, 2003). However, the predominance of biomedicine in the Croatian daily press is still not so strong. Although it covered about $30 \%$ of science news, the natural sciences accounted for about $20 \%$ and human and social sciences were very close to the same share (Table 3). About $75 \%$ of the news concerning biomedical sciences reported the results of research or applications from the field, but this was also the case with social and natural sciences. News from the humanities were significantly different since they were characterised by a high

Table 3. Science news by area of science $(\mathrm{N}=360)$.

\begin{tabular}{|c|c|c|c|}
\hline & Večernji list & Jutarnji list & Total \\
\hline Social sciences & $20.2 \%$ & $17.8 \%$ & $18.9 \%$ \\
\hline Human sciences & $17.8 \%$ & $23.4 \%$ & $20.8 \%$ \\
\hline Natural sciences & $20.9 \%$ & $21.3 \%$ & $21.1 \%$ \\
\hline Biomedical sciences & $27.0 \%$ & $29.4 \%$ & $28.3 \%$ \\
\hline Biotechnical sciences & $11.0 \%$ & $2.0 \%$ & $6.1 \%$ \\
\hline Technical sciences & $3.1 \%$ & $6.1 \%$ & $4.7 \%$ \\
\hline Total & $100.0 \%$ & $100.0 \%$ & $100.0 \%$ \\
\hline
\end{tabular}

$\chi^{2}=15.393, \mathrm{df}=5$, Sig. $=0.009$ 
proportion of presentations of scientific books, approximately the same amount as the number of news items regarding research results.

Although biomedical news was the most represented, the trustworthiness of reporting on this area in the Croatian press did not follow global journalistic trends. In terms of trustworthiness, biomedical sciences were convincingly the worst off out of all the fields in both daily papers, followed by the natural sciences (Graph 3). Graph 3 shows that most trustworthy reporting in both papers was on news from the fields of biotechnology and the humanities and social sciences.

Further evidence of the fact that biomedical sciences were reported as less trustworthy and more superficial than news from other fields of science can be seen from the following: about half of the articles on biomedicine used only general terms for the people involved, for example, "doctors", "Italian scientists", "Swedish physicians", while in a further $15 \%$ of articles, the people involved were not even mentioned. In contrast, more than half the articles gave the precise names of the relevant protagonists in the category of social sciences. Only about $15 \%$ of the relevant participants in biomedical articles were from Croatia, while, for example, more than half of them were from Croatia in news regarding the humanities.

As many as one third of articles published in Večernji list related to biomedicine were not signed, and another third were only signed with initials (Table 4). The impression is that Jutarnji list treated science news generally better than Večernji list, but the relationship towards the area of biomedicine was similar: the editors of Jutarnji list used agency sources for half the items of news in that field.

More than two thirds of news about biomedical sciences were published in sections and supplements of an entertaining and mixed character, and less

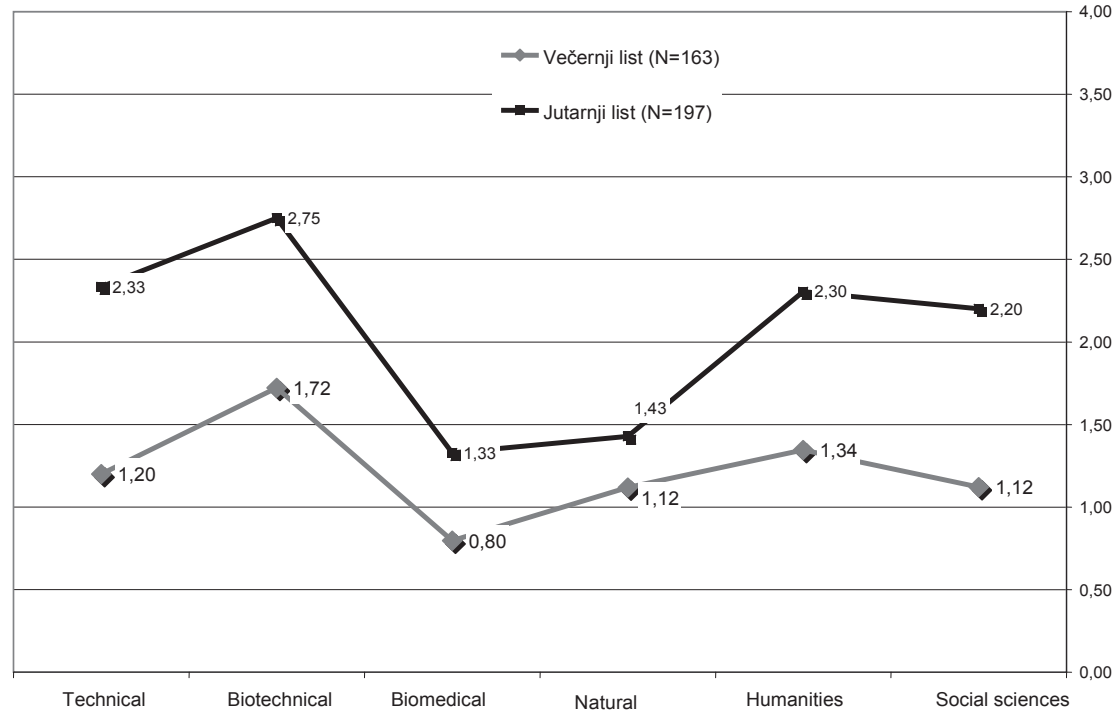

Graph 3. The average values of the trustworthiness index, by scientific field. 
Table 4. The authors of science news, by scientific field.

\begin{tabular}{|c|c|c|c|c|c|c|}
\hline & $\begin{array}{c}\text { SOCIAL } \\
\text { SCIENCES } \\
(\mathrm{N}=68)\end{array}$ & $\begin{array}{c}\text { HUMAN } \\
\text { SCIENCES } \\
(\mathrm{N}=75)\end{array}$ & $\begin{array}{c}\text { NATURAL } \\
\text { SCIENCES } \\
(\mathrm{N}=76)\end{array}$ & $\begin{array}{c}\text { BIOMEDICAL } \\
\text { SCIENCES } \\
(\mathrm{N}=102)\end{array}$ & $\begin{array}{c}\text { BIOTECHNICAL } \\
\text { SCIENCES } \\
(\mathrm{N}=22)\end{array}$ & $\begin{array}{c}\text { TECHNICAL } \\
\text { SCIENCES } \\
(\mathrm{N}=17)\end{array}$ \\
\hline Journalist & $52.9 \%$ & $38.7 \%$ & $44.7 \%$ & $27.5 \%$ & $40.9 \%$ & $88.2 \%$ \\
\hline $\begin{array}{c}\text { Expert- } \\
\text { scientist }\end{array}$ & $4.4 \%$ & $5.3 \%$ & $0.0 \%$ & $1.0 \%$ & $54.5 \%$ & $0.0 \%$ \\
\hline $\begin{array}{c}\text { Only initials } \\
\text { given }\end{array}$ & $10.3 \%$ & $18.7 \%$ & $13.2 \%$ & $22.5 \%$ & $4.5 \%$ & $5.9 \%$ \\
\hline $\begin{array}{c}\text { Agency } \\
\text { Unknown }\end{array}$ & $13.2 \%$ & $24.0 \%$ & $34.2 \%$ & $32.4 \%$ & $0.0 \%$ & $0.0 \%$ \\
\hline Total & $100.0 \%$ & $100.0 \%$ & $100.0 \%$ & $100.0 \%$ & $100.0 \%$ & $100.0 \%$ \\
\hline
\end{tabular}

than one third in sections and supplements of a serious nature. The situation with the natural sciences was similar (Table 5). This is also related to the fact that the news was often published without the names of the author and relevant participants; therefore it was not included in the serious sections.
Such "accommodation" of biomedical and natural science news inside the paper may also be the result of the editor's awareness of their information deficiencies. Just to make a comparison, over two thirds of news items from the humanities and over half of the news from the social sciences

Table 5. Science news in terms of the character of supplements and sections in which it is published, by scientific field.

\begin{tabular}{|c|c|c|c|c|c|c|}
\hline & $\begin{array}{c}\text { SOCIAL } \\
\text { SCIENCES } \\
(\mathrm{N}=68)\end{array}$ & $\begin{array}{c}\text { HUMAN } \\
\text { SCIENCES } \\
(\mathrm{N}=75)\end{array}$ & $\begin{array}{c}\text { NATURAL } \\
\text { SCIENCES } \\
(\mathrm{N}=76)\end{array}$ & $\begin{array}{c}\text { BIOMEDICAL } \\
\text { SCIENCES } \\
(\mathrm{N}=102)\end{array}$ & $\begin{array}{c}\text { BIOTECHNI- } \\
\text { CAL SCIENCES } \\
(\mathrm{N}=22)\end{array}$ & $\begin{array}{c}\text { TECHNICAL } \\
\text { SCIENCES } \\
(\mathrm{N}=17)\end{array}$ \\
\hline $\begin{array}{c}\text { Serious } \\
\text { supplements } \\
\text { and sections }\end{array}$ & $55.9 \%$ & $66.7 \%$ & $28.9 \%$ & $22.5 \%$ & $95.5 \%$ & $58.8 \%$ \\
\hline $\begin{array}{c}\text { Mixed } \\
\text { supplements } \\
\text { and sections }\end{array}$ & $20.6 \%$ & $13.3 \%$ & $25.0 \%$ & $27.5 \%$ & $.0 \%$ & $11.8 \%$ \\
\hline $\begin{array}{c}\text { Entertaining } \\
\text { supplements } \\
\text { and sections }\end{array}$ & $23.5 \%$ & $20.0 \%$ & $46.1 \%$ & $50.0 \%$ & $4.5 \%$ & $29.4 \%$ \\
\hline \multicolumn{1}{c|}{ Total } & $100.0 \%$ & $100.0 \%$ & $100.0 \%$ & $100.0 \%$ & $100.0 \%$ & $100.0 \%$ \\
\hline
\end{tabular}


were published in serious supplements and sections, which is in accord with the data on the trustworthiness of reporting in those fields.

\section{Discussion and Conclusion}

Overall, the proportion of articles about science in the analysed Croatian daily press correlates to some extent with the findings of foreign studies, where the proportion of scientific topics usually ranged between $1 \%$ and 5\% (Pellechia, 1997; Dimopoulos \& Kouladis, 2002). In view of Croatia's transitional social, $R \& D$ and media context, especially tabloidization and almost completely undeveloped domestic scientific journalism, we can even say that the Croatian printed media have an enviable proportion of articles related to science. We may ask ourselves whether this is perhaps a reflection of the sociohistorical tradition of "socially responsible" journalism and the declaratory political world view value given to science as a means of social progress, which finds its roots back in the socialist social system and ideology. But this is an open research problem, requiring a more complex diachronic approach and goes beyond the scope of this analysis.

However, the correlation between our and foreign results probably stems to a large degree from a different definition of scientific articles. Our study, in contrast to most foreign ones, included in its analysis articles referring to the social and humanistic disciplines, in order to gain a more comprehensive insight into the representation of scientific subjects. The proportion of articles thereby increased. However, more important than the proportion of science articles was the finding that they were very short, uninformative, characterised by a very superficial description and lack of crucial information. Neither of the two newspapers can boast of good and trustworthy reporting when it comes to science news. Moreover, in this qualitative dimension, the media image of the sciences can be seen in the lack of journalists' professionalism, not only due to the lack of a group of domestic journalists specialized in reporting on the sciences, but also due to the general erosion of journalistic criteria (Jergović, 2004a; 2004b).

Both daily papers lacked a systematic and analytical approach to reporting science news, whether in terms of the quantity or quality. However, Večernji list stood out in both senses as more superficial and more careless in its reporting; despite its longer tradition, it does not have a single journalist specialised exclusively in science news. Although Jutarnji list does not have a specialized science column, thanks to its one journalist specialized in covering science news, the paper showed slightly better results.

Carelessness, superficiality and the marginalization of science as subject matter were noticed in both papers when analysing thelocation of science news within the paper, the length of the articles and especially the journalistic and/or editorial approach to the news. This approach is characterised not only by a lack of additional information regarding sources, but also by the absence of basic information, from the actual source of the journalistic scientific story to the protagonists involved and to linking the causes and consequences. In this kind of approach, graphics, if used at all, were most often decorative and not at all informative.

The domination of biomedicine as a worldwide media trend (especially articles reporting applicable discoveries) was also noticed in Croatia and could be seen in the fact that the media featured news which emphasized the social and not the cognitive dimensions of science, that is, their application and close relationship with everyday life. However, despite the 
slight editorial/journalistic preference for news from the fields of biomedicine and the natural sciences, the media treatment of these areas was on a low level. In fact, it was much worse than the presentation of the humanities and social sciences.

The results showed that news about natural and especially biomedical sciences in the Croatian daily press had the status of incidental news, entertainment, news that "fills the gaps" on the back pages, and were taken from news agencies (Jutarnji list) or from unknown sources (Večernji list). This tells us that media reporting of the sciences is subject to the general media style of the time, marked by tabloidization and infotainment. In the case of natural and biomedical sciences, domestic sources were very rarely contacted and cited, and the domestic scientific elite in that field were truly neglected in the Croatian press. This may be explained by the domination of more relevant research and discoveries from other (more developed) countries, but also by the fact that the domestic scientific community is neither recognized by the media nor accustomed to public appearances. Their reluctance to appear in public, also reflected in the small proportion of expert articles, could be partially explained by the scientific community's heritage of a certain autonomy in which they did not have any real obligation or need for communication with the general public about their contribution to social development. Amongst Croatian scientific journals, the Croatian Medical Journal is the only medical journal that issues regular press-releases. Unfortunately, the results of this analysis clearly showed that the journalistic impact of these press releases, which is a common finding of foreign research, was lacking in the case of Croatia, especially in the biomedical sciences. In Western Europe and the USA, the custom of eminent scientific journals, primarily medical journals, is to publish press releases that contain a summary of the most interesting studies from individual issues. Some studies suggest that as much as 80 percent of news from medicine and other sciences published in daily papers are taken from these sources (Entwistle, 1995: 921; de Semir et al., 1998: 295).

On the other hand, the somewhat higher quality and more trustworthy approach as well as a larger proportion of social and human science news is in contrast to findings that suggest a higher epistemological status and representation of the natural and biomedical or "hard" sciences (Cassidy, 2008). This divergence may be connected to the prestige of the socialist media format, in which the social and humanistic disciplines were covered more often and with more information due to their function within political and ideological purposes. Although the media's social responsibility has changed, and it is not possible to speak of such frequent political instrumentalization of these scientific disciplines today, it is possible that it still exists within the social value system. On the other hand, their relatively solid and "trustworthy" treatment can also be explained by the fact that journalists in the Croatian media, by the logic of their education, are more often recruited from graduates of the humanities and social sciences faculties (Malović, 2002). Editors and journalists covering humanities and social topics are therefore more often educated professionals, who can show their interest and understanding of the topic in a deeper and more appropriate manner.

In order to point out the important implications of our analysis, we recall that the daily press is for the average reader an important source of information about science in Croatia, as well as elsewhere in the world. However, at the same time, the press both forms and reflects the public's interest in these subjects through its attitude 
towards science. In terms of media coverage and the trustworthiness of its treatment, science comes across in Croatian society as a somewhat neglected and marginalized topic, which few are interested in. Here we have in mind not just the culture/context, but also the characteristics of a poorly educated and uninterested audience to which a specific content is offered. In such social context, the media treatment of scientific topics is not surprising, and therefore neither are the results of this form of media communication.

Additionally, the poor educational structure of the population, the poverty level in the country and following international trends are all responsible for the widespread sensationalism and tabloidization (Vilović, 2003). Under the influence of the transitional factors and the influence of the international media, bringing commercialization and sensationalism in the approach to news, as well as tabloidization (Vilović, 2003), investigative journalism has not developed in this region. Instead, socalled pseudo-investigative journalism developed, characterised by unverified information, unfounded speculation and the disproportionate use of unnamed in relation to named sources (Vilović, 2003; 2004).

The social context of an uninterested and poorly educated public and the tabloidization of the media where ethics gave way to the aggressive demands of the market (Vilović, 2004), also affected science news. Our results have shown that news very often became only one form of entertainment, somewhere in between superficiality and sensationalism, and were often used to fill empty space at the last minute with news from agency sources. This trivialization and fragmentation of news, according to McNair (2003), affects the ability of the public to analyse information and act rationally.
The growing number of domestic public debates, such as those related to artificial insemination and the reorganization and financing of the scientific research sector, are based on scientific arguments. It is not necessary to point out the advantages of the participation of a scientifically literate and informed public. They are able to objectively assess the arguments in such debates, especially in the context of the mentioned dualism of the public perception of science as well as the gradual "democratization" of the domestic scientific research system. Where can the adult non-scientific public be expected to find information that can help them take an informed and objective part in decision-making, if not through the media?

The question is, who should we expect to offer better and higher quality content, taking into consideration the average journalist's educational level, as well as their journalistic culture. Since 2001, the Croatian Journalists' Association has only accepted members who are journalists with a university degree (Malović, 2000). However, the generational shift has been slow, and the number of poorly educated journalists is still high. A solution could perhaps be found in the greater inclusion of scientists in dialogue and the process of creating news related to their field. In that way, by engaging the scientists with media and public, not only could the level of trustworthy reporting of science news be raised, but also the public's trust in the reported information as well, which would result in a better informed public with greater involvement. According to research into the public's confidence in public figures and institutions, after the Church, Croatian citizens have most confidence in scientists (FPZ, 2009). Also, the results of European research show that scientists are the people in whom citizens have the most confidence when it comes to explaining the impact that 
science and technology have on society as a whole. The respondents were asked to rank the institutions and professions they believed were most qualified to explain to the public the impact of science and technology on the development of society as a whole. They first chose scientists working in public institutions or universities (52\%), then television journalists (32\%), scientists employed in private institutions (28\%), and finally journalists in daily newspapers $(25 \%)$ (Eurobarometar, 2005: 49). Furthermore, Hovland and Weiss's (1951) findings could support the involvement of scientists in media communication of science since they are perceived as potentially more trustworthy than other sources.

The conclusions of the Congress of Croatian Scientists from the Homeland and Abroad, held in 2007, pointed out the need for scientific institutions to aim their efforts towards better, more frequent and efficient communication with the press, as well as the need for journalists to be trained professionally so they are best able to cover and contextualize scientific topics. In line with the guidelines adopted and the increased awareness of the need to communicate with the media, a growing number of scientific conferences and workshops are being dedicated to scientists' education in communicating with the wider public. But only future research will be able to examine the specific results of these activities.

In conclusion, we consider the findings of this study, especially its implications, important on two levels. On the first level, they are significant from the perspective of knowledge and comparison since they pointed out certain characteristics of media presentation of the sciences in a transitional society, which are not only shaped by media and global changes in the relationship between science and society, but are also the product of a transitional context in which they arise and its socialist legacy. Further research into the media image of science in transitional countries should certainly integrate a developmental but also a comparative (international) aspect in order to enable the adequate contextualization of the findings.

On a second level, the findings are important from a practical perspective. They indicate that the Croatian scientific community should become more actively involved not only in drawing media attention to scientific topics and research, but also to the future participation in the scientific and technological policies of the country, as well as in dialogue with the public. On the other hand, Croatian journalists and editors should become aware of their social responsibility in providing information on science and technology, that is, in (co)creating the public's understanding of science, and in encouraging public participation in scientific and technological debates and policies. The media should develop a trustworthy, analytical and critical relationship towards science, respecting professional (and ethical), and not only the commercial criteria of their profession. The appropriate involvement of all participants in the process of the public communication of science is an important element in the development of what is known as a "knowledge society".

\section{Acknowledgements}

The authors of this paper would like to thank the agency Puls d.o.o. from Zagreb for supplying data on the circulation of daily papers in Croatia. This study was part of the project "Knowledge Elites in Scientific and Technological Development" financed by the Ministry of Science, Education and Sports of the Republic of Croatia (MSES). 


\section{Notes}

1 Bauer et al. (2006) notice the increase in the absolute number of scientific articles with a simultaneous reduction in terms of actual newspaper space.

2 Schaefer (2010) in meta-analysis of studies on the media's coverage of science noticed that analyses on nonWestern countries are extremly rare.

3 The ownership of the Croatian printed media is mainly in the hands of two media corporations: EPH and STYRIA, which demonstrates the concentration and concealed monopolization of the media (Vilović, 2003).

4 Agency Puls conducts regular "media consumption research" 365 days a year, by means of telephone surveys (CATI) on a stratified random sample (sex, age, level of education and county) of 115 people a day (805 a week, 41,975 a year). The survey is conducted not only for radio and television stations, but for all the relevant press in Croatia as well (13 daily papers and about 80 magazines). The survey includes respondents aged 15 and older who are able to read and write.

5 Citing is a method that journalists employ to reinforce the credibility of their data and enhance the content value (Kurtić, 2007).

6 Hovland \& Weiss (1951) analysed the influence of source credibility and noticed that trustworthy sources can more easily change the public's opinion than untrustworthy sources can.

7 According to the rules of the journalistic profession, journalists should have at least two independent sources (Kurtić, 2007).

8 Our study is exploratory and serves to define expectations and boundaries for future studies. Although consecutive day sampling can potentially limit generalizibility of findings, this techique is a) commonly used in content analysis (e.g. Sakura, 1993; de Semir et al., 1998; Elmer et al., 2008) and b) relatively representative because it captures variations in day to day coverage, avoiding oversampling individual weekdays (although constructed week procedure is more efficient; see Riffe et al. 1993).

9 Electronic archives of these dailies are incomplete and do not always contain complete articles.

10 The code matrix contains names of all sections and supplements. Later they were grouped by the authors into 3 categories: serious, entertainment and mixed, according to the agreed guidelines.

\section{References}

Anderson, A., Petersen, A., Wilkinson, C. \& S. Allan (2005) 'The framing of nanotechnologies in the British newspaper press', Science Communication 27(2): 200-220.

Bader, R. G. (1990) 'How science news sections influence newspaper science coverage: a case study', Journalism Quarterly 67(1): 88-96.

Bauer, M. (1998) "The medicalization of science news - from the "rocket-scalpel" to the "gene-meteorite" complex', Social Science Information 37(4): 731-751.

Bauer, M. (2000) 'Science in the media' as cultural indicator: contextualising surveys with media analysis,' in $\mathrm{M}$. Dierkes \& C. Von Grote (eds), Between understanding and trust: the public, science and technology (Amsterdam: Routledge):108-123.

Bauer, M. W., Petkova, K., Boyadjieva, P. \& G. Gornev (2006) 'Long-term trends in the public representation of science across the 'iron curtain': Britain and Bulgaria, 1946-95', Social Studies of Science 36(1): 99-131. 
Bucchi, M. \& R. G. Mazzolini (2003) 'Big science, little news: Science in the Italian daily press 1946-1997, Public Understanding of Science12(1): 7-24.

Cassidy, A. (2008) 'Communicating the social sciences', in Bucchi, M. \& B. Trench (eds), The Handbook of Public Communication of Science and Technology (London: Routledge): 225237.

Clayton, A., Hancock-Beaulieu, M. \& J. Meadows (1993) 'Change and continuity in the reporting of science and technology: a study of the Times and the Guardian', Public Understanding of Science 2(3): 225-234.

De Semir, V., Ribas, K. \& G. Revuelta (1998) 'Press releases of science journal articles and subsequent newspaper stories on the same topic,' The Journal of the American Medical Association 280(3): 294-295.

Dimopoulos, K. \& V. Koulaidis. (2002) 'The socio-epistemic constitution of science and technology in the Greek press: an analysis of its presentation', Public Understanding of Science 11(3): 225-241.

Dragojević, S., Kanižaj I. \& I. Žebec. (2006) 'Europska unija u hrvatskim dnevnim novinama: avis i odgoda pregovora / European Union in Croatian dailies: avis and postponing negotiations/ ', Politička misao 43(3): 133-164.

Durant, J., Evans, G. A. \& G. P. Thomas (1992) 'Public understanding of science in Britain: The role of medicine in the popular representation of science,' Public Understanding of Science 1(2): 161-182.

Elmer, C., Badenschier, F. \& H. Wormer (2008) 'Science for Everybody? How the coverage of research issues in German newspapers has increased dramatically', Journalism \& Mass Communication Quarterly 85(4): 878-893.

Entwistle, V. (1995) 'Reporting research in medical journals and newspapers', British Medical Journal 310: 920-923.
Eurobarometer 224 (2005) 'Europeans, science and technology', Brussels: European Commission, DirectorateGeneral for Press and Communication, Public Opinion Sector. Internet: http:// ec.europa.eu/public_opinion/archives/ ebs/ebs_224_report_en.pdf

Eurobarometer CC-EB $2002.3 \quad$ (2002) 'Public opinion in countries applying for European Union membership - Science \& Technology', Brussels: European Commission, Directorate-General for Press and Communication, Public Opinion Sector. Internet: http://europa. eu.int/comm/research/press/public opinion/

Eurobarometer 55.2 (2001) 'Europeans, science and technology', Brussels: European Commission, DirectorateGeneral for Press and Communication, Public Opinion Sector. Internet: http://europa.eu.int/comm/research/ press/2001/pr0612en-report.pdf

Evans, W. \& S. H. Priest (1995) 'Science content and social context', Public Understanding of Science 4(4): 327-340.

Guyot, J. (2009) 'Political-Economic Factors Shaping News Culture', in Preston, P. (ed), Making the news. Journalism and news cultures in Europe (London: Routledge): 135-149.

Hansen, A. (1994) 'Journalistic practices and science reporting in the British Press', Public Understanding of Science 3(2): 111-134.

Hilgartner, S. \& C. Bosk (1988) 'The rise and fall of social problems: a public arenas model', American Journal of Sociology 94(1): 53 - 78.

Hovland, C. I. \& W. Weiss (1951) 'The influence of source credibility on communication effectivness,' Public Opinion Quarterly 15(4): 633-650.

Jergović, B. (2004b) 'Rethinking the relationship between medicine and media: Two examples from Croatia, Croatian Medical Journal 45(4): 396-401. 
Jergović, B. (2004a) Odmjeravanje snaga: novine i politika u Hrvatskoj u prvom razdoblju tranzicije /Taking each other's measures. Newspapers and politics in Croatia in the first period of transition / (Zagreb: Sveučilišna knjižara).

Jerome, F. (1986) 'Gee wheez! Is that all there is?', in S. M. Friedman, S. Dunwoody \& C. L. Rogers (eds), Scientists and Journalists: Reporting Science as news (New York: Free Press): 147-154.

Kanižaj, I. (2007) 'Hrvatska: opća ispolitiziranost dnevnih listova /Croatia: newspapers politization /,' in S. Malovič (ed), Vjerodostojnost novina (Zagreb: ICEJ): 95-117.

Kronja, I. (2008) 'Čovjek tranzicije u masmedijskom društvu (slučaj Srbija) /The man of transition in mass-media society (case: Serbia)/,' Filozofska istraživanja 28(1): 97-106.

Kunac, S.\& S. Sarnavka (2006) Nevinost bez zaštite - ženska percepcija medijskih sadržaja / Women's perceptions of media content/ (Zagreb: B.a.b.e).

Kurtić, N. (2007) 'Konceptualizacija istraživanja /The conceptualization of research/,' in S. Malovič (ed), Vjerodostojnost novina (Zagreb: ICEJ): 39-66.

Lewenstein, B. W., (1995) 'Science and the media', in Jasanoff, S., Markle, G. E., Petersen, J. C. \& T. Pinch (eds), Handbook of Science and Technology (Sage: London): 343-360.

Malović, S. (2007) Vjerodostojnost novina / The credibility of newspapers / (Zagreb: ICEJ).

Malović, S. (2002) 'Hrvatska gorko-slatka iskustva: edukacija novinara u Hrvatskoj /Croatia's bitter-sweet experiences: Education of journalists in Croatia /,', in Jusič, T. \& M. Dedovič (eds), Obrazovanje novinara u jugoistočnoj Europi: korak bliže profesionalizmu (Sarajevo: Media Plan Institut): 55-69.
Malović, S. (2000) 'Stručnost - uvjet za profesionalnost /Knowledge and skills - Guarantee for professionalism/, Medijska istraživanja 6(2): 97-100.

Fakultet političkih znanosti /Faculty of Political Science/ (2009) 'Hrvatski novinari i mediji u očima gračana / Croatian journalists and media in the eyes of the citizens/', Internet - http://www.net. hr/tehnoklik/page/2009/11/18/0210006. html

McNair, B.(2003) Uvod u političku komunikaciju / Introduction to political communication / (Zagreb: FPZ).

Nelkin, D. (1995) Selling science: How the press covers science and technology (New York: Freeman).

Pellechia, M. G. (1997) 'Trends in science coverage: a content analysis of three US newspapers', Public Understanding of Science 6(1): 49-68.

Peruško Čulek, Z. (1999) Demokracija i mediji /Democracy and the media/ (Zagreb: Barbat).

Prpić, K. (2011) 'Science, the public, and social elites: How the general public, scientists, top politicians and managers perceive science,' Public Understanding of Science 20(6): 733-750.

Riffe, D., Aust, C.F. \& S. R. Lacy (1993) 'The Effectiveness of Random, Consecutive Day, and Constructed Week Sampling in Newspaper Content Analysis', Journalism Quarterly 70(1): 133-39.

Robinson, G. J. (1977) Tito's maverick media: The politics of mass communications in Yugoslavia (Urbana, Chicago, London: University of Illinois Press).

Schäfer, M. (2010) 'Taking a stock: a metaanalysis of studies on the media s coverage of science, Public Understanding of Science published online 1 December 2010 http://pus.sagepub.com/content/ early/2010/11/27/0963662510387559 
Skoko, B. \& D. Bajs (2007) 'Objavljivanje neistina i manipuliranje činjenicama u hrvatskim medijima i mogućnosti zaštite privatnosti, časti i ugleda / Reporting untruths and manipulating facts in croatian media, and possibilities for protecting privacy, honour and reputation/,' Politička misao 44(1): 93116.

Valković, J. (2009) 'Supsidijarnost u hrvatskom medijskom prostoru. Problemi i mogučnosti djelovanja / Subsidiarity in the Croatian media sphere. Problems and possible actions/,' Bogoslovska smotra 79(1): 113-146.

Van Dijck, J. (2003) 'After the "Two Cultures" toward a "(multi)cultural" practice of science communication,' Science Communication 25(2): 177-190.

Van Rooyen, C. (2002) 'A report on science and technology coverage in the SA print media Internet: http://www. saasta.ac.za/scicom/pdfs/setcoverage_ printmedia.pdf

Verhoeven, P. (2008) 'Where has the doctor gone? The mediazation of medicine on Dutch television, 1961-2000', Public Understanding of Science 17(4): 461 472.

Vilović, G. (2004) Etički prijepori u Globusu i Nacionalu 1999-2000 /Ethical Controversies in the Globus and the Nacional 1999-2000/ (Zagreb: FPZ).
Vilović, G. (2003) 'Istraživačko novinarstvo, tabloidizacija i etika / Investigative journalism, tabloidization and ethics /, Društvena istraživanja 68: 957-974.

Vujević, M. (2001) Politička i medijska kultura u Hrvatskoj / Political and media culture in Croatia/ (Zagreb: Školska knjiga).

Weigold, M. F. (2001) 'Communicating science. A review of the literature', Science Communication 23(2):164-193.

Weingart, P. (1998) 'Science and the media', Research Policy 27(8): 869-879.

Žlof, K. (2007) 'Važnost izvora za vjerodostojnost medija / Importance of sources for the credibility of the media l', in Malovič, S. (ed) Vjerodostojnost novina (Zagreb: ICEJ): 77-91.

Adrijana Šuljok

Institute for Social Research in Zagreb

Amruševa 8, 10000 Zagreb, Croatia

adrijana@idi.hr

Marija Brajdić Vuković

Institute for Social Research in Zagreb

Amruševa 8, 10000 Zagreb, Croatia

mare@idi.hr 